\title{
Antibodies against Apicomplexa protozoa and absence sarcocysts in heart tissues from horses in southern Brazil
}

Anticorpos contra protozoários do filo Apicomplexa e ausência de sarcocistos no miocárdio de equinos no sul do Brasil

Luiza Pires Portella ${ }^{1}$; Gustavo Cauduro Cadore ${ }^{1}$; Luis Antonio Sangioni ${ }^{1}$; Luiz Fernando Vilani Pellegrini²; Rafael Fighera ${ }^{3}$; Fernanda Ramos ${ }^{1}$; Fernanda Silveira Flores Vogel ${ }^{1 *}$

\author{
${ }^{1}$ Laboratório de Doenças Parasitárias, Departamento de Medicina Veterinária Preventiva - DMVP, Universidade Federal de Santa \\ Maria - UFSM, Santa Maria, RS, Brasil \\ ${ }^{2}$ Setor de Indústria e Inspeção de Carnes, Departamento de Medicina Veterinária Preventiva - DMVP, Universidade Federal de Santa \\ Maria - UFSM, Santa Maria, RS, Brasil \\ ${ }^{3}$ Laboratório de Patologia Veterinária, Universidade Federal de Santa Maria - UFSM, Santa Maria, RS, Brasil
}

Received July 13, 2016

Accepted September 19, 2016

\begin{abstract}
Sarcocystis spp., Neospora spp., and Toxoplasma gondii are Apicomplexa protozoa that can infect horses. This study aimed to investigate the occurrence of antibodies against Sarcocystis spp., Neospora spp., and T. gondii in horses slaughtered in southern Brazil. The presence of histological lesions, tissue cysts, and Sarcocystis spp. DNA in the hearts of these horses was also investigated. A total of 197 paired serum and heart samples were evaluated by serology and direct microscopic examination; 50 of these samples were subjected to histopathological and PCR analyses. Antibodies against at least one of the protozoa were detected in $146(74.1 \%)$ of the serum samples. The frequencies of positive serology were: $36 \%$ (71/197) against Sarcocystis spp., 39.1\% (77/197) against Neospora spp., and 47.2\% (93/197) against T. gondii. No cysts, Sarcocystis spp. DNA, or histopathological lesions were observed in myocardial tissue samples. The frequencies of antibody seropositivity against Sarcocystis spp., Neospora spp., and T. gondii showed that horses are frequently infected by these parasites in southern Brazil. The absence of sarcocysts in horse tissues is compatible with their role as aberrant/accidental hosts in the life cycle of Sarcocystis spp..
\end{abstract}

Keywords: Accidental hosts, epidemiology, Sarcocystis spp., Neospora spp., Toxoplasma gondii.

\section{Resumo}

Sarcocystis spp., Neospora spp. e Toxoplasma gondii são protozoários que pertencem ao filo Apicomplexa e que podem afetar equinos. O objetivo deste estudo foi investigar a ocorrência de anticorpos contra Sarcocystis spp., Neospora spp. e T. gondii. A presença de lesóes histológicas, cistos teciduais e DNA de Sarcocystis spp. no miocárdio de equinos abatidos no sul do Brasil também foi investigado. Um total de 197 amostras de soro juntamente com as respectivas amostras de coração, foram avaliadas por sorologia e exame microscópico direto. Destas amostras, 50 foram selecionadas e submetidas a análise histopatológica e PCR. Anticorpos contra pelo menos um dos protozoários foi detectado em $146(74,1 \%)$ das amostras de soro. As frequências de sorologia positiva foram: 36\% (71/197) para Sarcocystis spp., 39,1\% (77/197) para Neospora spp. e 47,2\% (93/197) para T. gondii. Não foram encontradas lesôes histopatológicas, cistos e DNA de Sarcocystis spp. nas amostras de miocárdio dos equinos. As frequências de soropositividade para Sarcocystis spp., Neospora spp. e T. gondii mostra que os equinos podem ser frequentemente infectados por estes parasitas no sul do Brasil. A ausência de sarcocistose no coração dos equinos é compatível com seu papel como hospedeiro errático/acidental no ciclo de vida deste protozoário.

Palavras-chave: Hospedeiro acidental, epidemiologia, Sarcocystis spp., Neospora spp., Toxoplasma gondii.

\footnotetext{
*Corresponding author: Fernanda Silveira Flores Vogel. Laboratório de Doenças Parasitárias, Departamento de Medicina Veterinária Preventiva, Universidade Federal de Santa Maria - UFSM, Av. Roraima, 1000, Prédio 44, Sala 5149, CEP 97105-900, Santa Maria, RS, Brasil. e-mail: fefevogel@gmail.com
} 


\section{Introduction}

Sarcocystis neurona, Neospora spp., and Toxoplasma gondii are Apicomplexa protozoan parasites that can cause encephalomyelitis in horses. Equine protozoal myeloencephalitis (EPM) is a severe and debilitating neurological disease that is most often caused by S. neurona (DUBEY et al., 2001a) and less frequently by Neospora hughesi (REED et al., 2016). Commonly, a diagnosis of EPM is based on neurological signs and serology indicating prior exposure to Sarcocystis spp. and/or Neospora spp. (RENIER et al., 2016). Clinical signs depend on the distribution of the parasite in the central nervous system (DUBEY et al., 2001a). Equines become infected with $S$. neurona by ingesting sporocysts excreted in the feces of opossums (Didelphis spp.), which are definitive hosts for the pathogen (FENGER et al., 1995; DUBEY et al., 2001a). Horses are generally considered accidental hosts of this protozoan (DUBEY et al., 2006). However, Mullaney et al. (2005) suggested that horses can act as natural intermediate hosts of $S$. neurona, since cysts have been found within their muscle tissues.

T. gondii and Neospora spp. are biologically similar protozoa (DUBEY et al., 2009). Neosporosis is a widely recognized reproductive disease in cattle caused by Neospora spp.; this agent can also cause EPM (HAMIR et al., 1998). Horses can be infected by both $N$. caninum and $N$. hughesi; however, EPM seems to be caused specifically by $N$. hughesi (REED et al., 2016). Toxoplasmosis is a zoonotic disease caused by $T$. gondii and the infection with this protozoan in horses is usually subclinical (AL-KHALIDI \& DUBEY, 1979). However, clinical signs of infection, including hyperirritability, motor incoordination, ocular disorders, and abortions, have been reported (DUBEY \& PORTERFIELD, 1986). Therefore, considering the importance of Apicomplexa protozoa as etiologies of neurological diseases in horses, the objectives of this study were to investigate (a) the presence of antibodies against Sarcocystis spp., Neospora spp., and T. gondii in horses slaughtered in Rio Grande do Sul, Brazil, and (b) the presence of histological lesions, tissue cysts, and Sarcocystis spp. DNA in the hearts of these horses.

\section{Materials and Methods}

\section{Animals and samples}

Heart tissues and serum samples of 197 horses were collected from a slaughterhouse located in São Gabriel, Rio Grande do Sul, Brazil. The samples were collected between September and November 2014. The animals were clinically healthy horses, ranging from 6 months to 18 years of age and originating from two states of southern Brazil: Rio Grande do Sul and Paraná. Collected blood samples were centrifuged at $250 \times g$ for 10 minutes to obtain serum and then stored at $-20{ }^{\circ} \mathrm{C}$ until testing. Harvested heart tissue samples $(50 \mathrm{~g})$ were stored individually in plastic bags and kept refrigerated until processing.

\section{Direct examination and histopathology}

Each heart tissue sample was directly examined. Approximately $25 \mathrm{~g}$ of tissue from each sample was macerated and homogenized with phosphate-buffered saline (PBS; $0.1 \mathrm{M}$ phosphate,
$0.33 \mathrm{M} \mathrm{NaCl}, \mathrm{pH}$ 7.2) and filtered with gauze. This homogenate was examined for sarcocysts using an inverted microscope at $400 \times$. For the histopathological examination, 50 of the 197 heart tissue samples were randomly selected, sectioned transversely, and fixed in $10 \%$ formaldehyde. Samples were steam autoclaved after 7 days of formaldehyde fixation, and then processed for histology and stained with hematoxylin and eosin. The resulting material was analyzed by light microscopy.

\section{$D N A$ extraction and polymerase chain reaction (PCR)}

Total DNA was extracted from approximately $50 \mathrm{mg}$ of each heart tissue sample using a commercial kit (Wizard Genomic DNA Purification Kit, Promega, Madison, WI, USA) according to the manufacturer's instructions, with modifications in the lysis step, as outlined by Moré et al. (2011).

Total DNA was subjected to PCR, using primers specific for the $18 \mathrm{~S}$ rDNA region of Sarcocystis spp. (forward: 5'-CGCAAATTACCCAATCCTGA-3' and reverse: 5'-ATTTCTCATAAGGTGCAGGAG-3'). The PCR reaction was performed in a total volume of $25 \mu \mathrm{L}$, containing $5 \mu \mathrm{L}$ of buffer, $100 \mathrm{ng}$ of each primer; $10 \mathrm{mM}$ deoxynucleotide triphosphate (dNTPs); 1 U of DNA polymerase GoTaq ${ }^{\circledR}$ (Hot Start Polymerase, Promega, Madison, WI, USA), and $100 \mathrm{ng}$ of total DNA used as a template. Amplification was performed with an initial denaturation for $4 \mathrm{~min}$ at $95^{\circ} \mathrm{C}$; followed by 40 cycles of denaturation for $40 \mathrm{sec}$ at $94^{\circ} \mathrm{C}$, annealing for $30 \mathrm{sec}$ at $59{ }^{\circ} \mathrm{C}$, and extension for $60 \mathrm{sec}$ at $72^{\circ} \mathrm{C}$; with a final extension for $6 \mathrm{~min}$ at $72^{\circ} \mathrm{C}$. The PCR products were visualized by UV illumination after electrophoresis on a $1 \%$ agarose gel stained with GelRed ${ }^{\circledR}$ (Biotium Inc., CA, USA).

\section{Antibody survey}

Anti-Sarcocystis spp., anti-Neospora spp., and anti-T. gondii immunoglobulin G (IgG) antibodies were detected by indirect fluorescence antibody test (IFAT) on separate slides. Antigens used to detect antibodies were merozoites of $S$. neurona (SN-37R strain) cultivated in CV-1 cells, tachyzoites of $N$. caninum (NC-1 strain), and tachyzoites of T. gondii (RH strain), all maintained in Vero cells. The cell were cultured in RPMI 1640 culture medium (Invitrogen, Brazil), supplemented with 10\% fetal bovine serum (Nutricell, Brazil) at $37^{\circ} \mathrm{C}$ under $5 \% \mathrm{CO}_{2}$.

Serum samples were diluted 1:50 in PBS, and equine sera that were known to be positive or negative for the tested protozoa were used as controls. Commercial fluorescein-labeled anti-equine IgG (Goat Anti-Equine IgG FITC ${ }^{\circledR}, 160$ A, Southern Biotech, Birmingham, USA) was used as the secondary antibody. Slides were observed at $400 \times$ magnification using a fluorescent microscope (Leica CTR 4000/EBQ 100, Leica Microsystems, Germany). Samples with titers $\geq 50$ were considered positive.

\section{Results}

Serologic results for the 197 horses evaluated by IFAT showed that $146(74.1 \%)$ were positive for antigens of at least one of the protozoa. The frequency of detection of antibodies 
against each of the protozoa were the following: 36\% (71/197) anti-Sarcocystis spp., 39.1\% (77/197) anti-Neospora spp., and 47.2\% (93/197) anti-T. gondii. Mixed infection by Sarcocystis spp. and Neospora spp. occurred in 5.6\% (11/197) of the horses, while $11.7 \%$ (23/197) were positive for Sarcocystis spp. and T. gondii, and equines infected by Neospora spp. and T. gondii was $12.7 \%$ (25/197). In 19 (9.6\%) serum samples, antibodies were detected against all three protozoa. The antibody seropositivity of horses for Sarcocystis spp., Neospora spp., or T. gondii alone were 9.1\% (18/197), 12.2\% (24/197), and 13.2\% (26/197), respectively.

No sarcocysts were found in the 197 cardiac muscle tissue by direct examination. Of the 50 cardiac muscle samples subjected to histopathological examination and PCR, 25 (50\%) were from animals seropositive for Sarcocystis spp. antibodies. No Sarcocystis spp. DNA was amplified by PCR of the 50 samples tested. Furthermore, no morphological alterations, lesions, or tissue cysts consistent with Sarcocystis spp. infection were observed in the histopathological analysis.

\section{Discussion}

Serological analysis indicated a frequency of 36\% (71/197) seropositivity to Sarcocystis spp. in clinically healthy horses slaughtered in southern Brazil. This result was similar to the $35.6 \%$ seropositivity found in 101 thoroughbreds in Brazil (DUBEY et al., 1999a). In addition, Hoane et al. (2006) detected seropositivity to $S$. neurona in $69.6 \%$ of horses tested in Brazil. These results indicate consistent, widespread distribution of this parasite in Brazil. This is probably a result of the free access of definitive hosts to horse pastures and feed, resulting in broad environmental contamination by sporocysts and oocysts from this protozoan. Didelphis albiventris is a broadly distributed opossum that was confirmed to be definitive host of $S$. neurona in South America (DUBEY et al., 2001b) and due to its synanthropy, this species is a potential disseminator of pathogens between domestic animals and man (MULLER et al., 2005).

An antibody seropositivity of 39.1\% (77/197) against Neospora spp. is relatively high when compared with another study performed in southern Brazil, in which $15.4 \%$ seropositivity was found in draft horses (SANGIONI et al., 2011) and 23.9\% detected in horses from state of Minas Gerais (RIBEIRO et al., 2016). Moreover, Hoane et al. (2006) detected a very low prevalence (2.5\%) of antibodies against Neospora spp. in Brazilian horses. Neosporosis in horses has been described in several countries with different infection rates, which may be a result of environmental conditions, sampling methods, or the type of tests used for diagnosis (DUBEY et al., 1999a, b). Regardless of the variation, these results indicate that Neospora spp. infection is significant in the horses tested. Environmental contamination by oocysts excreted by dogs is a potential route for infection of horses by N. caninum (GONDIM et al., 2004); however, the transplacental route also allows Neospora spp. to be maintained in horse populations (DUBEY \& PORTERFIELD, 1990). Based in these results, the neosporosis should be included in the differential diagnosis as a potential etiologic agent of EPM in southern Brazil.

Toxoplasmosis is a zoonosis of great interest due to its impact on public health and that can be transmitted through consumption of raw or undercooked meat (DUBEY \& SU, 2009). T. gondii infections in equines have been reported in Brazil, with variable antibody detection rates (DUBEY et al., 1999a; RIBEIRO et al., 2016). In the present study, seropositivity to T. gondii was $47.2 \%$ (93/197), which is high when compared to similar studies (DUBEY et al., 1999a, b), but similar results were found in Egypt (GHAZY et al., 2007). In state of Minas Gerais, Brazil, Ribeiro et al. (2016) showed a wide dispersion of $T$. gondii among horse farms, revealing that in $71.6 \%$ of the assessed farms, at least one presented one seropositive equine. The great differences in seroprevalence may be associated with various factors, including the type of feed given and the source of the water provided to animals; the intrinsic resistance to infection of horses tested; the population density of domestic or wild cats in the environment; environmental conditions; and the type of diagnostic test used (KOUAM et al., 2010). The high frequencies of antibodies detected against each of the parasites tested might be related to the origin of the blood samples. Although only clinically normal horses were sampled, it is important to highlight that most $(85 \%)$ of these animals were over 10 years of age, which increases the probability of horizontal infection.

Despite the importance of $S$. neurona as an etiologic agent of EPM, the epidemiology of this protozoan disease in horses is not completely known. There are three other Sarcocystis species that infect equines and form cysts in their muscle tissue, S. bertrami, S. equicanis, and S. fayeri (LEVINE, 1986). Therefore, equine cardiac muscle was examined for sarcocysts to investigate whether these horses could serve as intermediate hosts in the parasite's life cycle. For most authors, in spite of the clinical importance of EPM, equines are considered as accidental hosts of $S$. neurona, where the infection does not determine the tissue cysts formation (DUBEY et al., 2006). However, Mullaney et al. (2005) found sarcocysts in the tongue muscle tissue of a horse with clinical signs of EPM, and they confirmed the presence of $S$. neurona DNA by restriction fragment length polymorphism and PCR. Thus, more studies are needed to clarify the epidemiological role of horses in the life cycle of this protozoan. In this study, no cysts or Sarcocystis spp. DNA were detected in the myocardium tissue samples evaluated, reinforcing the idea that infected horses act as accidental or final hosts of the parasite. S. neurona infection in Brazil is associated with cases of EPM (MASRI et al., 1992) and the presence of the definitive host D. albiventris (DUBEY et al., $2001 \mathrm{~b}$ ). This opossum is frequently encountered in rural areas, and usually lives in forests. However, with an increase in deforestation, the opossums are in closer proximity to farms and urban areas, increasing the possibility of environmental contamination and potential for infection of horses (DUBEY et al., 2001a).

\section{Conclusion}

The high frequencies of antibody seropositivity against Sarcocystis spp., Neospora spp., and T. gondii in clinically healthy horses showed that these animals are at risk of infection by Apicomplexa parasites in southern Brazil. The absence of sarcocysts in the heart tissues of anti-Sarcocystis spp. seropositive horses is compatible with their role as aberrant/accidental hosts in the life cycle of $S$. neurona. 


\section{References}

Al-Khalidi NW, Dubey JP. Prevalence of Toxoplasma gondii infection in horses. J Parasitol 1979; 65(2): 331-334. PMid:448624. http://dx.doi. org/10.2307/3280181.

Dubey JP, Chapman JL, Rosenthal BM, Mense M, Schueler RL. Clinical Sarcocystis neurona, Sarcocystis canis, Toxoplasma gondii and Neospora caninum infections in dogs. Vet Parasitol 2006; 137(1-2): 36-49. PMid:16458431. http://dx.doi.org/10.1016/j.vetpar.2005.12.017.

Dubey JP, Jenkins MC, Kwok OCH, Zink RL, Michalski ML, Ulrich $\mathrm{V}$, et al. Seroprevalence of Neospora caninum and Toxoplasma gondii antibodies in white-tailed deer (Odocoileus virginianus) from Iowa and Minnesota using four serologic tests. Vet Parasitol 2009; 161(3-4): 330334. PMid:19285809. http://dx.doi.org/10.1016/j.vetpar.2009.01.002.

Dubey JP, Kerber CE, Granstrom DE. Serologic prevalence of Sarcocystis neurona, Toxoplasma gondii and Neospora caninum in horses in Brazil. J Am Vet Med Assoc 1999a; 215(7): 970-972. PMid:10511862.

Dubey JP, Lindsay DS, Kerber CE, Kasai N, Pena HPJ, Gennari SM, et al. First isolation of Sarcocystis neurona from the South American opossum, Didelphis albiventris, from Brazil. Vet Parasitol 2001b; 95(2-4): 295-304. PMid:11223209. http://dx.doi.org/10.1016/S0304-4017(00)00395-2.

Dubey JP, Lindsay DS, Saville WJA, Reed SM, Granstrom DE, Speer CA. A review of Sarcocystis neurona and equine protozoal myeloencephalitis (EPM). Vet Parasitol 2001a; 95(2-4): 89-131. PMid:11223193. http:// dx.doi.org/10.1016/S0304-4017(00)00384-8.

Dubey JP, Porterfield ML. Toxoplasma-like sporozoa in an aborted equine fetus. J Am Vet Med Assoc 1986; 188(11): 1312-1313. PMid:3087925.

Dubey JP, Porterfield ML. Neospora caninum (Apicomplexa) in an aborted equine fetus. J Parasitol 1990; 76(5): 732-734. PMid:2213418. http:// dx.doi.org/10.2307/3282991.

Dubey JP, Su C. Population biology of Toxoplasma gondii: what's out and where did they come from. Mem Inst Oswaldo Cruz 2009; 104(2): 190-195. PMid:19430643. http://dx.doi.org/10.1590/S0074-02762009000200011.

Dubey JP, Venturini MC, Venturini L, McKinney J, Pecoraro M. Prevalence of antibodies to Sarcocystis neurona, Toxoplasma gondii and Neospora caninum in horses from Argentina. Vet Parasitol 1999b; 86(1): 59-62. PMid:10489203. http://dx.doi.org/10.1016/S0304-4017(99)00127-2.

Fenger CK, Granstrom DE, Langemeier JL, Stamper S, Donahue JM, Patterson JS, et al. Identification of opossums (Didelphis virginiana) as the putative definitive host of Sarcocystis neurona. J Parasitol 1995; 81(6): 916-919. PMid:8544064. http://dx.doi.org/10.2307/3284040.

Ghazy AA, Shaapan RM, Abdel-Rahman EH. Comparative serological diagnosis of toxoplasmosis in horses using locally isolated Toxoplasma gondii. Vet Parasitol 2007; 145(1-2): 31-36. PMid:17174034. http:// dx.doi.org/10.1016/j.vetpar.2006.11.010.

Gondim LF, McAllister MM, Pitt WC, Zemlicka DE. Coyotes (Canis latrans) are definitive hosts of Neospora caninum. Int J Parasitol 2004; 34(2): 159-161. PMid:15037103. http://dx.doi.org/10.1016/j.ijpara.2004.01.001.

Hamir AN, Tornquisyt SJ, Gerros TC, Topper MJ, Dubey JP. Neospora caninum-associated equine protozoal myeloencephalitis. Vet Parasitol
1998; 79(4): 269-274. PMid:9831950. http://dx.doi.org/10.1016/ S0304-4017(98)00178-2.

Hoane JS, Gennari SM, Dubey JP, Ribeiro MG, Borges AS, Yai LEO, et al. Prevalence of Sarcocystis neurona and Neospora spp. infection in horses from Brazil based on presence of serum antibodies to parasite surface antigen. Vet Parasitol 2006; 136(2): 155-159. PMid:16310955. http:// dx.doi.org/10.1016/j.vetpar.2005.10.023.

Kouam MK, Diakou A, Kanzoura V, Papadopoulos E, Gajadhar AA, Theodoropoulos G. A seroepidemiological study of exposure to Toxoplasma, Leishmania, Echinococcus and Trichinella in equids in Greece and analysis of risk factors. Vet Parasitol 2010; 170(1-2): 170-175. PMid:20197215. http://dx.doi.org/10.1016/j.vetpar.2010.02.004.

Levine ND. The taxonomy of Sarcocystis (Protozoa, Apicomplexa) species. J Parasitol 1986; 72(3): 372-382. PMid:3091802. http://dx.doi. org/10.2307/3281676.

Masri MD, Alda JL, Dubey JP. Sarcocystis neurona-associated ataxia in horses in Brazil. Vet Parasitol 1992; 44(3-4): 311-314. PMid:1466140. http://dx.doi.org/10.1016/0304-4017(92)90128-V.

Moré G, Abrahamovich P, Jurado S, Bacigalupe D, Marin JC, Rambeaud M, et al. Prevalence of Sarcocystis spp. in Argentinean cattle. Vet Parasitol 2011; 177(1-2): 162-165. PMid:21168276. http://dx.doi.org/10.1016/j. vetpar.2010.11.036.

Mullaney T, Murphy AJ, Kiupel M, Bell JA, Rossano MG, Mansfield LS. Evidence to support horses as natural intermediate hosts for Sarcocystis neurona. Vet Parasitol 2005; 133(1): 27-36. PMid:15970386. http:// dx.doi.org/10.1016/j.vetpar.2005.05.016.

Muller G, Brum JGW, Langoni PQ, Michels GH, Sinkoc AL, Ruas JL, et al. Didelphis albiventris Lund, 1841, parasitado por Ixodes loricatus Neumann, 1899, e Amblyomma aureolatum (Pallas, 1772) (Acari: Ixodidae) no Rio Grande do Sul. Arq Inst Biol 2005; 72(3): 319-324.

Reed SM, Furr M, Howe DK, Johnson AL, MacKay RJ, Morrow JK, et al. Equine Protozoal Myeloencephalitis: an updated consensus statement with a focus on parasite biology, diagnosis, treatment, and prevention. $J$ Vet Intern Med 2016; 30(2): 491-502. PMid:26857902. http://dx.doi. org/10.1111/jvim.13834.

Renier AC, Morrow JK, Graves AJ, Finno CJ, Howe DK, Owens SD, et al. Diagnosis of equine protozoal myeloencephalitis using indirect fluorescent antibody testing and enzyme-linked immunosorbent assay titer ratios for Sarcocystis neurona and Neospora hughesi. J Equine Vet Sci 2016; 36: 49-51. http://dx.doi.org/10.1016/j.jevs.2015.10.010.

Ribeiro MJM, Rosa MHF, Bruhn FRP, Garcia AM, Rocha CMBM, Guimarães AM. Seroepidemiology of Sarcocystis neurona, Toxoplasma gondii and Neospora spp. among horses in the south of the state of Minas Gerais, Brazil. Braz J Vet Parasitol 2016; 25(2): 142-150. PMid:27334814. http://dx.doi.org/10.1590/S1984-29612016029.

Sangioni LA, Botton SA, Cargnelutti JF, Cadore GC, Cezar AS, Weiblen $\mathrm{R}$, et al. Pesquisa de anticorpos anti-Neospora spp. e anti-herpersvírus equino em cavalos de tração no município de Santa Maria, RS, Brasil. Cienc Rural 2011; 41(2): 321-323. http://dx.doi.org/10.1590/S010384782011000200023. 